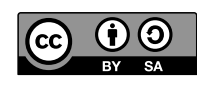

DOI: $10.4312 / \mathrm{mz} .57 .1 .229-253$

UDK 37.015.31:78:616-036.22"2020/2021"

\title{
Poučevanje glasbene umetnosti na daljavo v osnovnošolskem izobraževanju med epidemijo covid-19
}

\author{
Tina Bohak Adam, Mira Metljak \\ University of Ljubljana
}

\begin{abstract}
IZVLEČEK
Namen raziskave je bil ugotoviti raven digitalne pismenosti in izkušnje učiteljev glasbene umetnosti v osnovnošolskem izobraževanju s poučevanjem na daljavo v obdobju pred razglasitvijo epidemije covid-19 in po njej. Izsledki potrjujejo dvig ravni digitalne pismenosti v navedenem obdobju in kažejo na pozitivne izkušnje z uporabo informacijsko-komunikacijske tehnologije v praksi.
\end{abstract}

Ključne besede: digitalna pismenost, poučevanje na daljavo, osnovna šola, učitelji glasbene umetnosti, covid-19

\begin{abstract}
The study's purpose was to determine the level of digital literacy and experience in distance teaching of music art teachers in primary school education in the period before and after the declaration of the COVID-19 epidemic. The results confirm the increase in digital literacy level in that period and show positive experiences with information and communication technology in practice.
\end{abstract}

Keywords: digital literacy, distance learning, primary school, music art teachers, COVID-19 


\section{Uvod}

Digitalna pismenost je ena temeljnih vseživljenjskih kompetenc, ki vključuje varno in kritično uporabo tehnologije informacijske družbe pri učenju, raziskovanju, umetniškem ustvarjanju in delu, pa tudi v prostem času in pri komunikaciji. ${ }^{1}$ Je posameznikova elementarna zmožnost, da se znajde $\mathrm{v}$ digitalnem svetu. Digitalno pismen posameznik pozna in uporablja osnovna znanja $\mathrm{v}$ informacijsko-komunikacijski tehnologiji (v nadaljevanju: IKT), kot so na primer: uporaba računalnikov za iskanje, ocenjevanje, shranjevanje, proizvodnjo, predstavitev in izmenjavo informacij ter za sporazumevanje in sodelovanje v skupnih omrežjih po internetu. ${ }^{2}$ Izsledki kažejo, da je digitalna pismenost pravzaprav širše umeščen pojem in ga lahko razumemo kot nadpomenko, pod katero uvrščamo tudi digitalno kompetenco (glej spodaj) ter vsaj še področje varne in kritične uporabe IKT. ${ }^{3}$

\section{Ključne kompetence in Evropski okvir digitalnih kompetenc za učitelje - DigCompEdu (2017)}

Pojem kompetenca je v 60. letih 20. stoletja v organizacijsko znanost uvedel ameriški psiholog David McClelland (1917-1998). Menil je, da za uspešno delo posameznika niso potrebne le spretnosti, znanje in veščine, ki jih posameznik razvije $z$ učenjem, ampak tudi njegove osebnostne značilnosti, kot so npr. njegova spretnost, intuitivnost, vztrajnost in motiviranost. ${ }^{4}$ Izoblikoval je tudi svoj prvi kompetenčni model, v katerem je poudaril, da se kompetenc ne učimo, ampak jih razvijamo. Inteligenco namreč merijo inteligenčni testi, inteligenca pa velikokrat ni nujna oz. ni pogoj za dobro opravljanje nekega dela, gotovo pa pripomore $\mathrm{k}$ njenemu izboljšanju. ${ }^{5}$

Treba je poudariti, da je bil McClelland pravzaprav zelo napreden v svojem razmišljanju, saj se je njegovo pojmovanje kompetence precej razlikovalo od do zdaj tradicionalnih obravnav posameznika in je do njegovega časa le

1 »Digitalna pismenost, « Portal Osnovne spretnosti in veščine, dostop 11. marec 2020, https://www. portalosv.si/digitalna-pismenost/;PetraJavrh,»Digitalna pismenost nasprotidigitalnikompetenci,« European Commission, EPALE - ePlatforma za izobraževanje odraslih v Evropi, dostop 11. marec 2020, https://epale.ec.europa.eu/s1/blog/digitalna-pismenost-nasproti-digitalni-kompetenci.

2 »Digitalna pismenost,« Portal Osnovne spretnosti in veščine.

3 "The European Digital Strategy, European Commission, Strategy, Shaping Europe's digital future, dostop 11. marec 2020, https://ec.europa.eu/digital-single-market/en/content/europeandigital-strategy.

4 David Clarence McClelland, "Testing for Competence Rather Than for 'Intelligence', "American Psychologist 28, št. 1 (1973): 1-14, dostop 27. februar 2020, https://www.therapiebreve.be/ documents/mcclelland-1973.pdf; Rado Wechtersbach, »Digitalna kompetenca in njeno izgrajevanje, Organizacija 42, št. 1 (2009): A1-A2, http://www.dlib.si/?URN=URN:NBN:SI:DOC-QK8BF35D.

5 Clarence McClelland, »Testing for Competence.» 
redko kdo natančno vedel, kaj kompetence pravzaprav so oz. kaj natančno pomenijo. ${ }^{6}$

Poudarjamo, da se pojem kompetenca $\mathrm{v}$ današnjem času vse več uporablja, da pa je njegovo pojmovanje še vedno precej neenotno in opredeljeno s številnimi različnimi definicijami. Izraz je prisoten tudi v pogovornem jeziku, a če se osredotočimo na definicijo v Slovarju slovenskega knjižnega jezika, ugotovimo, da je kompetenca opredeljena kot »obseg, mera odločanja, določena navadno z zakonom; pristojnost, pooblastilo«, lahko pa jo opredelimo tudi kot "področje dejavnosti ${ }^{7}$.

Svet Evropske unije je na predlog Evropske komisije leta 2000 v Lizboni sklenil, da mora evropski okvir v procesu zagotavljanja vseživljenjskega učenja na novo opredeliti osnovna znanja kot ključni ukrep pri odzivu Evrope na globalizacijo in premik k družbi znanja. Zasnovano je bilo poročilo, ki ga je Svet leta 2001 sprejel, in tako je postalo razvijanje veščn ena izmed prednostnih nalog izobraževanja. ${ }^{8}$ Naj poudarimo, da je v tem letu začela delovati tudi delovna skupina Evropske komisije o temeljnih veščinah (Working Group on Basic Skills, Enterpreneurship and Foreign Languages). Njeni člani so kljub številnim razhajanjem glede konceptov in opredelitev temeljnih veščin dve leti pozneje (2003) izdali poročilo, ki predstavlja osnovo za reševanje tega vprašanja. V njem so namesto izraza »veščine« uvedli izraz »kompetenca«. Prav tako so namesto izraza »temeljne« uvedli izraz »ključne«. ${ }^{9}$ Ključne kompetence tako opredeljujemo kot kombinacijo znanja, spretnosti in odnosov, ki ustrezajo okoliščinam..$^{10}$

V aktualnem Priporočilu Sveta Evropske unije o ključnih kompetencah za vseživljenjsko učenje iz leta 2018 je opredeljenih osem ključnih kompetenc, in sicer: 1. pismenost; 2. večjezičnost; 3. matematična, naravoslovna, tehniška in inženirska kompetenca; 4. digitalna kompetenca; 5. osebnostna, družbena in učna kompetenca; 6. državljanska kompetenca; 7. podjetnostna kompetenca; 8. kulturna zavest in izražanje. $V$ času do leta 2018 so bile opredeljene kompetence večkrat preimenovane in drugače razporejene. ${ }^{11}$

Pojmovanje izraza digitalne kompetence se največkrat navezuje na ustrezno in varno rabo celotnega nabora digitalnih tehnologij, ki povezujejo ljudi s podatki, omogočajo komunikacijo in pomagajo pri reševanju problemov na

6 Wechtersbach, »Digitalna kompetenca in njeno izgrajevanje, «A2.

7 »Kompetenca, « Slovar slovenskega knjižnega jezika, dostop 10. februar 2020, https://fran.si/130/ sskj-slovar-slovenskega-knjiznega-jezika/3554184/kompetenca?FilteredDictionaryIds=130\&View $=1 \&$ Query=kompetenca.

8 Wechtersbach, Digitalna kompetenca in njeno izgrajevanje, « Zgodovina v šoli 20, št. 3/4 (2011):4.

9 Prav tam.

10 Priporočilo Sveta z dne 22. maj 2018 o ključnih kompetencah za vseživljenjsko učenje, Uradni list Evropske unije, 4. 6. 2018, str. C189/1, dostop 26. februar 2020, https://eur-lex.europa.eu/ legal-content/SL/TXT/PDF/?uri=CELEX:32018H0604(01)\&from=EN.

11 Prav tam. 
različnih področjih delovanja, torej na računalnike in $z$ njimi povezan IKT. $^{12}$ Prav tako lahko ta izraz pojmujemo kot posameznikove značilnosti in veščine, ki se izražajo kot njegovo znanje, spretnosti, motivi, vrednote, prepričanja in vse drugo, kar potrebuje, da uspešno in učinkovito ter skladno s standardi delovne uspešnosti in pričakovanji izvrši določeno nalogo ali opravi delo z IKT. Digitalno kompetenten posameznik je z njeno uporabo uspešnejši, ustvarjalnejši in inovativnejši, uporablja veljavne in zanesljive podatke ter se zaveda pravnih in etičnih načel uporabe te tehnologije. ${ }^{13}$

Razumevanje digitalnih kompetenc je ključnega pomena za izobraževanje in delo ter za aktivno participacijo v sodobni družbi in gospodarstvu. ${ }^{14} \mathrm{Njihovo}$ izgrajevanje mora biti funkcionalno prisotno pri vseh ciljih izobraževanja in v kontekstu reševanja problemov v celotnem kurikulumu. Takšno poučevanje zahteva večji napor, večjo zavzetost ter več časa in znanja učiteljev. ${ }^{15}$

Poudarjamo, da je digitalne kompetence treba obravnavati kot prečne kompetence, ki pomembno vplivajo na pridobivanje drugih ključnih kompetenc, kot so npr. komunikacijske in jezikovne spretnosti ali osnovne spretnosti na področju matematike in naravoslovja ter kulturna zavest in izražanje. ${ }^{16}$

Digitalne kompetence je mogoče določiti v sklopu Evropskega okvira digitalnih kompetenc, ki ga je pripravila Evropska unija. Razdeljen je na več področij, in sicer: DigComp 2.1 (2017), katerega prva izdaja je izšla leta 2003 in je namenjen vsem državljanom, ${ }^{17}$ DigCompOrg (2015), ki je namenjen izobraževalnim ustanovam, ${ }^{18}$ in $\operatorname{DigCompEdu}(2017)$, ki je namenjen učiteljem oz. izo-

12 Matej Urbančič in dr., Strokovne podlage za didaktično uporabo IKT v izobraževalnem procesu za področje umetnosti, 4, dostop 17. januar 2020, http://ikt-projekti.uni-lj.si/porocila/strokovne\%20 podlage\%20umetnost.pdf.

13 Wechtersbach, »Digitalna kompetenca in njeno izgrajevanje, A3 .

14 Riina Vuorikari, »Razvoj digitalnih kompetenc: naloga državljana 21. stoletja,« School Education Gateway - Evropska spletna platforma za šolsko izobraževanje, dostop 13. januar 2020, https:// www.schooleducationgateway.eu/s1/pub/viewpoints/experts/riina_vuorikari_-_becoming_dig. htm; »Digitalna kompetenca - vitalna veščina 21. stoletja za učitelje in učence, « School Education Gateway - Evropska spletna platforma za šolsko izobraževanje, dostop 13. januar 2020, https:// www.schooleducationgateway.eu/sl/pub/resources/tutorials/digital-competence-the-vital-.htm.

15 Wechtersbach, Digitalna kompetenca in njeno izgrajevanje,« A4.

16 Riina Vuorikari, »Razvoj digitalnih kompetenc: naloga državljana 21. stoletja,«; Urbančič in dr., Strokovne podlage za didakticno uporabo IKT, 4.

17 Carretero Stephanie, Riina Vuorikari in Yves Punie, DigComp 2.1: The Digital Competence Framework for Citizens with eight proficiency levels and examples of use (JointResearch Centre, European Commission, 2017), dostop 25. februar 2020, https://publications.jrc.ec.europa.eu/repository/ bitstream/JRC106281/web-digcomp2.1pdf_(online).pdf; Carretero Stephanie, Riina Vuorikari in Yves Punie, DigComp 2.1: Okvir digitalnih kompetenc za državljane; Osem ravni doseganja kompetenc in primeri rabe; Prevod (Ljubljana: Zavod RS za šolstvo, 2017).

18 Panagiotis Kampylis, Yves Punie in Jim Devine, Promoting Effective Digital-Age Learning - A European Framework for Digitally-Competent Educational Organisations (JointResearch Centre, European Commission, 2015), dostop 5. marec 2020, https://publications.jrc.ec.europa.eu/repository/bitstream/JRC98209/jrc98209_r_digcomporg_final.pdf. 
braževalcem. ${ }^{19}$ Ključni cilj vseh teh okvirov je poenotenje kategorij, ki omogočajo mednarodno primerljiv in skladen jezik za opisovanje ključnih kompetenc ter določajo lestvice, s katerimi je mogoče opredeliti raven doseženih kompetenc. Prav tako je mogoče na podlagi teh okvirov lažje spremljati napredovanja na ravni posameznika in prepoznati potrebe po nadaljnjem usposabljanju. ${ }^{20}$

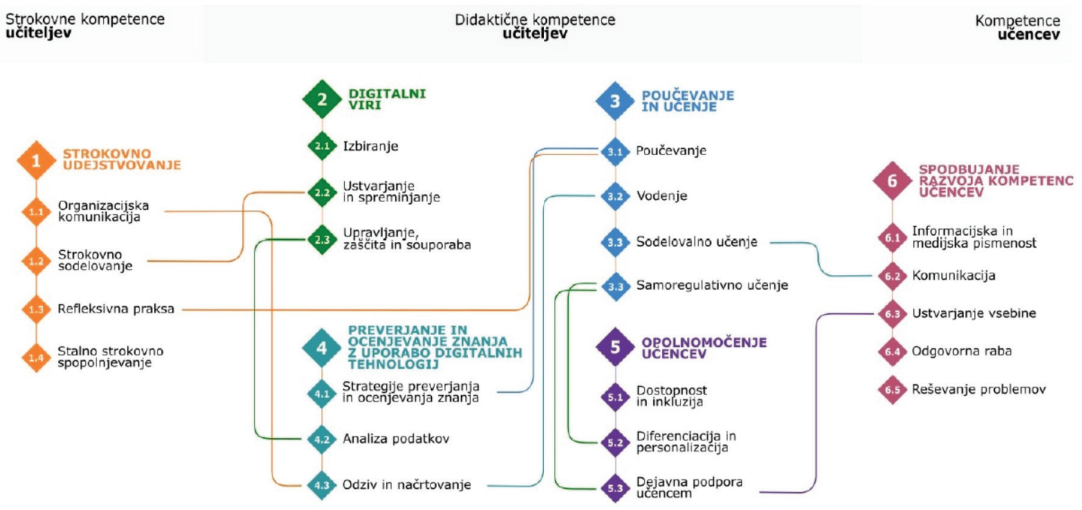

Shema 1: Okvir digitalnih kompetenc, kot ga opredeljuje DigCompEdu (2017). ${ }^{21}$

Strokovni okvir kompetenc za učitelje je namenjen učiteljem oz. izobraževalcem na vseh ravneh izobraževanja od zgodnjega otroštva do višješolskega izobraževanja in izobraževanja za odrasle, vključno s splošnim in poklicnim izobraževanjem, $\mathrm{z}$ izobraževanjem oseb s posebnimi potrebami ter učenjem $\mathrm{v}$ neformalnih okvirih. Opredeljuje šest osrednjih področij razvoja: 1. strokovno udejstvovanje; 2. digitalne vire; 3. poučevanje in učenje; 4 . preverjanje in ocenjevanje znanja $z$ uporabo digitalnih tehnologij; 5 . opolnomočenje učencev; 6 . spodbujanje razvoja kompetenc učencev. $V$ njih je skupno poudarjenih 22 temeljnih kompetenc, ki se povezujejo v poljih učiteljevih strokovnih kompetenc, pedagoških kompetenc in kompetenc učencev. Te morajo učitelji obvladati, da lahko kakovostno opravljajo svoje pedagoško delo $\mathrm{z}$ uporabo IKT in tudi vse $\mathrm{s}$ tem delom povezane dejavnosti. ${ }^{22}$

19 Christine Redecker, European Framework for the Digital Competence of Educators: DigCompEdu. (JointResearch Centre, European Commission, 2017), dostop 25. februar 2020, https://ec.europa. eu/jrc/en/publication/eur-scientific-and-technical-research-reports/european-frameworkdigital-competence-educators-digcompedu; Christine Redecker, Evropski okvir digitalnih kompetenc izobraževalcev: DigCompEdu (Ljubljana: Zavod RS za šolstvo, 2017), dostop 25. februar 2020, https://www.zrss.si/digitalnaknjiznica/DigCopEdu/2/.

20 Urbančič in dr., Strokovne podlage za didaktično uporabo IKT, 4.

21 Christine Redecker, Evropski okvir digitalnih kompetenc izobraževalcev: DigCompEdu.

22 Prav tam, 7 in 14. 
Kot osrednje poudarjamo didaktične kompetence, ki zajemajo znanje in spretnosti s področij učenja in poučevanja. Prav tako so pomembne tudi strokovne kompetence, ki vključujejo organizacijo, sporočanje, strokovno sodelovanje in kakovostno refleksijo oz. samoevalvacijo opravljenega dela. Seveda pa ne smemo izpustiti digitalnih kompetenc učencev, kamor sodijo: informacijska pismenost, sposobnost komunikacije $\mathrm{z}$ digitalnimi orodji in $\mathrm{s}$ storitvami, znanje za ustvarjanje digitalnih gradiv, odgovorna raba digitalnih virov in kritična udeležba $\mathrm{v}$ javni digitalni sferi ter reševanje problemov $\mathrm{Z}$ uporabo IKT. ${ }^{23}$

DigCompEdu gotovo predstavlja temeljno izhodišče za analizo, evalvacijo in za nadgradnjo kompetenčnih opredelitev $\mathrm{v}$ celotnem izobraževalnem sistemu, saj le tako lahko učitelj oz. izobraževalec celostno pristopi k poučevanju.

\section{Vključevanje IKT v osnovnošolsko glasbeno izobraževanje}

$\mathrm{V}$ današnjem času opažamo korenit razvoj IKT tudi na področju glasbe. Glasbena tehnologija pomaga posamezniku oblikovati, artikulirati in kakovostneje razumeti zvok. Pomeni veliko več kot le uporabo ustrezne strojne in programske opreme, različnih notacijskih programov in multimedijskih predstavitev glasbene zgodovine. Prav razvoj na področju strojne in programske opreme je omogočil kakovostnejše poučevanje in učenje. ${ }^{24}$ Zgodile so se velike spremembe $\mathrm{v}$ načinu izvajanja, komponiranju, kupovanju in $\mathrm{v}$ izmenjavi glasbenih posnetkov oz. vsebin. Lahko bi rekli, da je glasba v najrazličnejših oblikah na svetovnem spletu tako rekoč dostopna »vsakomur v vsakem trenutku«. ${ }^{25}$

Vključevanje IKT v pouk glasbene umetnosti dandanes še vedno predstavlja bolj izziv kot ustaljeno prakso. Kurikularna prenova na osnovnošolski ravni (2011) je prinesla vključitev oz. opis razvoja digitalne kompetence v okviru vseh učnih načrtov. Cilji in vsebine zgoraj omenjenega učnega načrta omogočajo veliko možnosti za učinkovito in ustvarjalno uporabo IKT pri pouku. ${ }^{26}$ Uporaba digitalne tehnologije pri glasbenem pouku mora biti skladna s cilji, opredeljenimi $\mathrm{v}$ aktualnih učnih načrtih, prav tako je poudarjeno medpredmetno povezovanje, npr. iskanje glasbenih informacij na svetovnem spletu, ustvarjanje, snemanje, predvajanje glasbe, digitalno opismenjevanje itn.

24 Peter Richard Webster, "Computer-Based Techology and Music Teaching and Learning: 2000-2005, « v International Handbook of Research in Arts Education, ur. Liora Bressler (Dordrecht: Springer, 2007), vol. 16: 1311-1330; Jožko Lango, »Poučevanje glasbene vzgoje $\mathrm{z}$ uporabo informacijsko-komunikacijske tehnologije, « (doktorska disertacija, Univerza v Ljubljani, 2011), 68.

25 Inge Breznik, Smernice za uporabo IKT pri predmetu glasbena umetnost vosnovni šoli in glasba v gimnaziji (Ljubljana: Zavod Republike Slovenije za šolstvo, 2016), 2, dostop 20. februar 2020, https:// www.zrss.si/digitalnaknjiznica/smernice-ikt-gum/files/assets/basic-html/index.html\#1. 
Glasbena tehnologija pripravlja učence na aktivno sprejemanje glasbe in njeno vrednotenje. ${ }^{27}$

Sodobna glasbenopedagoška teorija in praksa poudarjata pomen dejavnostno naravnane glasbene vzgoje. Pri njenem poučevanju je velikega pomena razvijanje posameznikovih glasbenih sposobnosti, spretnosti in znanja. Učenje se usmerja na razvijanje glasbene inteligence, ki ni pomembna le za glasbeni razvoj, ampak tudi za razvoj sposobnosti mišljenja, pa tudi za sodobno multimedijsko komunikacijo. ${ }^{28}$ Učenje naj bo torej aktivna konstrukcija znanja in potrebuje tako učno okolje, ki bo z interakcijo glasbenih dejavnosti spodbujalo aktivno pridobivanje glasbenih izkušenj. Tako učenci z glasbenim izvajanjem, $s$ poslušanjem in $z$ ustvarjanjem oblikujejo glasbeno védenje. ${ }^{29}$ IKT ne sme biti prevladujoč pripomoček za poučevanje glasbe, ampak orodje za podporo poučevanju ter krepitev oz. bogatenje učenja in branja..$^{30}$

Pomembno vlogo pri vključevanju IKT v glasbeni pouk ima učitelj, od katerega se zahteva ustrezna digitalna pismenost oz. več časa za načrtovanje in pripravo pouka. Prav tako so za učitelja neizogibna stalna IKT-izobraževanja in strokovna izpopolnjevanja, kar je morda eden izmed razlogov, da se marsikateri učitelj raje poslužuje tradicionalnih oblik poučevanja. ${ }^{31}$ Prenekateri učitelj oz. izobraževalec računalnik, internet in drugo tehnologijo razume kot novo orodje za doseganje tradicionalnih, že preverjenih ciljev, manj pa kot možnost inovativnega izobraževanja. Posledično IKT-oprema pri pouku velikokrat ostane neuporabljena. ${ }^{32}$ Tako izobraževalci nehote vplivajo na omejitev radovednosti in ustvarjalnosti učencev oz. dijakov, ti so pa v veliki večini povsem odprti za nove možnosti. ${ }^{33}$ Tako ne čudi, da je $\mathrm{v}$ današnjem času uvajanje IKT v pouk bolj domena mlajših učiteljev, ki so že med študijem pridobili odlično vsebinsko, tehnološko in didaktično znanje ter ga uporabljajo oz. ga bodo s pridom uporabljali v praksi oz. razredu.

Posebej je treba poudariti, da mora učitelj ob tem poznati ustrezna programska orodja in storitve za podporo sodobnim metodam poučevanja. Samoiniciativno mora iskati, razvijati in preizkušati možnosti za učinkovito uporabo informacijsko-komunikacijsko tehnologijo ter jo kritično vrednotiti, uvajati na učenca usmerjene učne dejavnosti, prožne oblike dela, ustvarjalne naloge in inovativne projekte ter $\mathrm{v}$ največji meri upoštevati potrebe in zahteve

Lango, »Poučevanje glasbene vzgoje $\mathrm{z}$ uporabo informacijsko-komunikacijske tehnologije, « 75; Urbančič in dr., Strokovne podlage za didaktično uporabo IKT, 15.

28 Lango, "Poučevanje glasbene vzgoje z uporabo informacijsko-komunikacijske tehnologije, 4.

29 Prav tam, 11.

30 Prav tam, IV-V.

31 Rotar Pance in Bohak Adam, »Vključevanje informacijsko-komunikacijske tehnologije, "264; Urbančič in dr., Strokovne podlage za didaktično uporabo IKT, 12.

32 Prav tam, 21.

33 Wechtersbach, Digitalna kompetenca in njeno izgrajevanje,«A1-A2. 
posameznikov. ${ }^{34}$ Prav tako si mora prizadevati, da poišče in ustrezno predstavi glasbene vsebine, ki imajo dokazano umetniško in kulturno vrednost. Številne izvedbe, ki nam jih ponuja svetovni splet, omogočajo primerjalno obravnavo posameznih glasbenih del in spodbujajo kritično senzibilnost dijakov. Ti naj dobijo tudi ustrezne spodbude za projektno raziskovalno delo na področju glasbe. IKT zagotavlja konstruktivno učno okolje, v katerem dijaki poiščejo probleme in načine njihovega raziskovanja, manipulirajo z zvoki itn. Vse njihove individualne dejavnosti naj potekajo po načelu learning by doing, tudi $z$ didaktično uporabo IKT pri pouku glasbene umetnosti. ${ }^{35}$ IKT zelo dobro podpira tudi sodelovalno učenje, ki zahteva spremembo vloge učitelja. Ta predvsem učinkoviteje pripravlja učne vsebine in sestavo pouka ter predvidi dejavnosti in vključevanje učencev v učni proces. ${ }^{36}$ Med izvajanjem učnih dejavnosti spremlja delo učencev, jim daje povratne informacije in jim svetuje. ${ }^{37}$ Široka množica možnosti IKT omogoča učitelju oz. izobraževalcu načrtovanje učinkovite in kreativne rabe pri glasbenem pouku, npr. pri ugotavljanju predznanja učencev oz. dijakov, usvajanju novih pojmov, preverjanju in ocenjevanju znanja, domačem delu, komunikaciji z učenci oz. med učenci in dijaki, sodelovalnem in projektnem delu, pri predstavitvi rezultatov dela itn. ${ }^{38}$

Ob tem se vprašamo, kako je raba sodobne tehnologije povezana tudi z odraščanjem posameznika. Vsekakor ugotavljamo, da je v današnjem času IKT za učence oz. dijake izziv ter hkrati motiv za omogočanje individualnosti izražanja in svobode $\mathrm{v}$ drugačnosti. Zdi se, da je ustvarjalna uporaba IKT pri pouku glasbene umetnosti tako rekoč nujnost, saj so učenci oz. dijaki vsakodnevno v stiku s sodobno tehnologijo in so pri njeni rabi zelo spretni, hkrati pa so tudi $\mathrm{v}$ razvojnem obdobju, v katerem jim glasba predstavlja pomemben element identifikacije. ${ }^{39}$ Vendarle pa ne gre zanemariti dejstva, da je uporaba IKT v izobraževalnem procesu smiselna le ob hkratni edukaciji in pod nadzorom učitelja oz. izobraževalca. Učence oz. dijake je treba navajati na odgovorno, kritično in varno rabo sodobne tehnologije.

Uporaba IKT je vedno odvisna tudi od opremljenosti glasbenih učilnic oz. ustrezne strojne in programske opreme, a ne prinese nujno dobrih rezultatov. Uspešno delo je namreč hkrati odvisno od digitalne pismenosti učiteljev in njihove naklonjenosti uvajanju sodobnih tehnologij v pouk. ${ }^{40}$ Opažamo, da je

Urbančič in dr., Strokovne podlage za didaktično uporabo IKT, 4.

Rotar Pance in Bohak Adam, »Vključevanje informacijsko-komunikacijske tehnologije,« 276.

Matjaž Debevc, Jernej Weiss, Andrej Šorgo in Ines Kožuh, »Solfeggio Learning and the Influence of a Mobile Application Based on Visual, Auditory and Tactile Modalities, « British Journal of Educational Technology 51, št. 1 (2020): 177-193, https://doi.org/10.1111/bjet.12792.

Urbančič in dr., Strokoune podlage za didaktično uporabo IKT, 4.

Breznik, Smernice za uporabo IKT pri predmetu glasbena umetnost, 4.

Prav tam, 3.

Lango, »Poučevanje glasbene vzgoje z uporabo informacijsko-komunikacijske tehnologije,«V 
realnost pogosto daleč od želenega, saj nakup ustrezne strojne in programske opreme marsikateri osnovni šoli še vedno predstavlja problem.

\section{Pouk glasbene umetnosti med epidemijo}

Izbruh koronavirusne bolezni (covid-19) po svetu in pri nas je korenito spremenil ne le naša življenja, ampak tudi celotno družbo, gospodarstvo in tudi celotno vertikalo izobraževalnega sistema. Zaradi razglasitve epidemije je v obdobju med marcem in junijem 2020 več kot 190 držav po svetu zaprlo vrata svojih šol ter z uporabo IKT vpeljalo nove izobraževalne pristope, ki bi omogočili kakovostno nadaljnje izobraževanje več kot 1,57 milijarde učencev po svetu. ${ }^{41}$

12. marca 2020 je bila zaradi povečanja nevarnosti širjenja koronavirusne bolezni v Sloveniji razglašena epidemija. ${ }^{42}$ Istega dne je bila objavljena tudi Odredba o prepovedi zbiranja ljudi v zavodih s področja vzgoje in izobraževanja ter univerzah in samostojnih visokošolskih zavodih, ki je od učencev in izobraževalcev v celotni vertikali izobraževalnega sistema pravzaprav zahtevala nove prilagoditve za poučevanje brez osebnega stika in skladno $\mathrm{z}$ javnoveljavnim učnim načrtom. ${ }^{43} \mathrm{~V}$ tem obdobju je do 1 . junija 2020, ko je bil uradno razglašen konec epidemije v Sloveniji, ${ }^{44}$ tudi pouk glasbene umetnosti v osnovnošolskem izobraževanju potekal na daljavo. Učitelji so se bili primorani v zelo kratkem času spoprijeti $z$ bolj ali manj učinkovito uporabo IKT, ne glede na njihovo predznanje oz. afinitete do vpeljave tovrstnih tehnologij v pouk glasbene umetnosti. Posledično so pridobili dragocene izkušnje na tem področju in dvignili raven digitalne pismenosti, ki je - kot ugotavljamo - za nemoteno izvajanje izobraževalnega sistema izjemnega pomena.

\section{Namen in cilji raziskave}

Namen raziskave je bil ugotoviti raven digitalne pismenosti učiteljev glasbene umetnosti $\mathrm{v}$ osnovnošolskem izobraževanju in pridobiti njihove izkušnje

41 »UNICEF and Microsoft launch global learning platform to help address covid-19 education crisis, «Unicef, dostop 27. oktober 2020, https://www.unicef.org/press-releases/unicef-and-microsoft-launch-global-learning-platform-help-address-covid-19-education; Natalija Šimunovič, "Poučevanje inštrumenta v času epidemije covid-19," Glasbenopedagoški zbornik Akademije za glasbo v Ljubljani 16, št. 32 (2020): 17-18.

42 Odredba o razglasitvi epidemije nalezljive bolezni SARS-CoV-2 (covid-19) na območju Republike Slovenije, 12. marec 2020, Uradni list RS, št. 19/2020, dostop 27. oktober 2020, https://www. uradni-list.si/glasilo-uradni-list-rs/vsebina/2020-01-0532.

43 Odredba o prepovedi zbiranja ljudi v zavodih s področja vzgoje in izobraževanja ter univerzah in samostojnih visokošolskih zavodih, 12. marec 2020, Uradni list $R S$, št. 19/20, 22/20 in 25/20, dostop 27. oktober 2020, http://www.pisrs.si/Pis.web/pregledPredpisa?id=ODRE2547\#.

44 Odlok o preklicu epidemije nalezljive bolezni SARS-CoV-2 (covid-19), 14. 5. 2020, Uradni list $R S$, št. 68/2020, dostop 27. oktober 2020, https://www.uradni-list.si/glasilo-uradni-list-rs/ vsebina/2020-01-1030/. 
z uporabo IKT v praksi v obdobju pred 12. marcem 2020, ko je bila uradno razglašena epidemija covid-19 (v nadaljevanju: pred epidemijo covid-19), ter med njenim trajanjem do delitve spričeval v šolskem letu 2019/20 (12.3. 2020-24. 6. 2020) (v nadaljevanju: po epidemiji covid-19).

Cilji raziskave so bili ugotoviti, v kolikšni meri in za kateri namen so učitelji pred epidemijo covid-19 pri pouku glasbene umetnosti uporabljali IKT, katera spletna programska orodja so pri tem uporabljali pred epidemijo covid-19 in po njej, ali oz. katere težave so imeli učitelji oz. učenci pri pouku na daljavo med epidemijo covid-19 oz. po njej, kako ocenjujejo svoje znanje uporabe in stopnjo digitalne pismenosti, na kakšen način in na katerem področju so se izobraževali oz. si pridobivali in nadgrajevali znanje iz varne in kritične uporabe IKT pri pouku in ali si tega želijo tudi $\mathrm{v}$ prihodnje, ter $\mathrm{v}$ kolikšni meri bodo $\mathrm{v}$ prihodnje uporabljali IKT in na katerih področjih.

\section{Raziskovalna vprašanja, metoda in opis vzorca}

RV 1: Ali so se pri učiteljih glasbene umetnosti pojavljale razlike pred epidemijo covid-19 in po njej glede uporabe spletne učilnice pri pouku glasbene umetnosti?

RV 2: Ali so se pri učiteljih glasbene umetnosti pojavljale razlike pred epidemijo covid-19 in po njej glede uporabe drugih spletnih platform oz. aplikacij pri pouku glasbene umetnosti?

RV 3: Ali so se pri učiteljih glasbene umetnosti pojavljale razlike pred epidemijo covid-19 in po njej glede ocene znanja uporabe IKT pri pouku glasbene umetnosti?

RV 4: Ali so se pri učiteljih glasbene umetnosti pojavljale razlike pred epidemijo covid-19 in po njej glede ocene stopnje digitalne pismenosti?

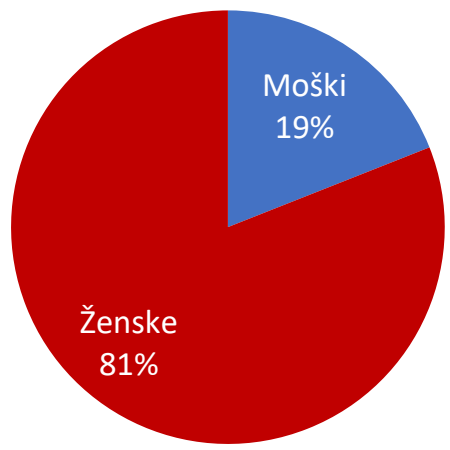

Shema 2: Sestava anketiranih učiteljev glasbene umetnosti glede na spol. 
V raziskavi smo uporabili kvantitativni raziskovalni pristop. Osnovni raziskovalni metodi sta bili deskriptivna in kavzalno-neeksperimentalna metoda.

$\mathrm{V}$ raziskavi je sodelovalo 83 osnovnošolskih učiteljev glasbene umetnosti. 67 je bilo žensk in 16 moških (glej Shemo 2).

Anketirani učitelji glasbene umetnosti v osnovni šoli poučujejo od enega do štirideset let, povprečno 20,54 leta.

\section{Postopek zbiranja in obdelave podatkov}

Vprašalnik smo pripravili v spletni obliki 1KA (EnKlikAnketa), povezava pa je bila učiteljem glasbene umetnosti posredovana po elektronski pošti po več poteh. Vprašalnik je bil odprt dva tedna. Podatke smo izvozili in jih obdelali v programu za statistično obdelavo podatkov SPSS. Na ravni deskriptivne statistike smo uporabili frekvenčno porazdelitev $(f, f \%)$ atributivnih spremenljivk ter mere srednjih vrednosti in razpršenosti (aritmetična sredina in standardni odklon) za numerične spremenljivke, na ravni inferenčne statistike pa hi-kvadrat preizkus hipoteze neodvisnosti oz. Kullbackov 2̂ิ-preizkus, in sicer tam, kjer pogoj za uporabo hi-kvadrat preizkusa ni bil izpolnjen, ter t-test za parne primerjave. Uporabljeni so veljavni odstotki glede na število anketirancev, ki so odgovorili na posamezno vprašanje. Podatki so prikazani $\mathrm{v}$ tabelah.

\section{Rezultati z interpretacijo}

$\mathrm{V}$ nadaljevanju predstavljamo rezultate izvedene ankete.

Tabela 1: V kolikšni meri so učitelji pred epidemijo covid-19 pri pouku glasbene umetnosti uporabljali IKT?

\begin{tabular}{l|r|r}
\cline { 2 - 3 } & $\boldsymbol{f}$ & $\boldsymbol{f} \%$ \\
\hline nisem uporabljal/-a & 4 & 4,8 \\
\hline manj kot $50 \%$ & 27 & 32,5 \\
\hline $50 \%-69 \%$ & 19 & 22,9 \\
\hline $70 \%-89 \%$ & 17 & 20,5 \\
\hline $90 \%$ ali več & 16 & 19,3 \\
\hline skupaj & $\mathbf{8 3}$ & $\mathbf{1 0 0 , 0}$ \\
\hline
\end{tabular}

Največ anketirancev, skoraj tretjina, je odgovorila, da so pred epidemijo covid-19 pri pouku glasbene umetnosti IKT uporabljali v manj kot $50 \%$, štirje ga niso uporabljali. V $90 \%$ in več ga je uporabljala skoraj petina (19,3\%). 
Tabela 2: Za kateri namen so učitelji pred epidemijo covid-19 najpogosteje uporabili IKT pri pouku glasbene umetnosti?

\begin{tabular}{lr|r}
\cline { 2 - 3 } & $f$ & $f \%$ \\
\hline $\begin{array}{l}\text { kot didaktični pripomoček pri svojem delu - predvajanje } \\
\text { avdioposnetkov }\end{array}$ & 19 & 24,1 \\
\hline $\begin{array}{l}\text { kot didaktični pripomoček pri svojem delu - predvajanje } \\
\text { videoposnetkov }\end{array}$ & 34 & 43,0 \\
\hline kot didaktični pripomoček pri svojem delu - predvajanje prezentacij & 11 & 13,9 \\
\hline kot pripomoček za delo učencev (ustvarjanje ...) & 7 & 8,9 \\
\hline drugo & 8 & 10,1 \\
\hline skupaj & $\mathbf{7 9}$ & $\mathbf{1 0 0 , 0}$ \\
\hline
\end{tabular}

$\mathrm{Na}$ vprašanje, za kateri namen so najpogosteje uporabljali IKT pri pouku glasbene umetnosti pred epidemijo covid-19, jih je največ (43,0 \%) odgovorilo, da so to tehnologijo najpogosteje uporabljali kot didaktični pripomoček pri njihovem delu, in sicer za predvajanje videoposnetkov. Četrtina jih je najpogosteje uporabljala IKT za predvajanje avdioposnetkov, slaba desetina $(8,9 \%)$ kot pripomoček za delo učencev. Pod drugo so zapisali, da so uporabljali vse našteto, eden je uporabljal notografski program, ${ }^{45}$ eden spletno učilnico itn.

RV 1: Ali so se pri učiteljih glasbene umetnosti pojavljale razlike pred epidemijo covid-19 in po njej glede uporabe spletne učilnice pri pouku glasbene umetnosti?

Tabela 3: Uporaba spletne učilnice pred epidemijo covid-19 in po njej ter vrednost hi-kvadrat preizkusa

\begin{tabular}{c|l|r|r|r}
\cline { 3 - 5 } \multicolumn{2}{c|}{} & $\boldsymbol{d a}$ & $\boldsymbol{n e}$ & skupaj \\
\hline \multirow{2}{*}{ pred } & $\mathrm{F}$ & 10 & 72 & 82 \\
\cline { 2 - 5 } & $\mathrm{f} \%$ & $12,2 \%$ & $87,8 \%$ & $100,0 \%$ \\
\hline \multirow{2}{*}{ po } & $\mathrm{F}$ & 45 & 37 & 82 \\
\cline { 2 - 5 } & $\mathrm{f} \%$ & $54,9 \%$ & $45,1 \%$ & $100,0 \%$ \\
\hline \multirow{2}{*}{ skupaj } & $\mathbf{f}$ & $\mathbf{5 5}$ & $\mathbf{1 0 9}$ & $\mathbf{1 6 4}$ \\
\cline { 2 - 5 } & $\mathbf{f} \%$ & $\mathbf{3 3 , 5} \%$ & $\mathbf{6 6 , 5} \%$ & $\mathbf{1 0 0 , 0} \%$ \\
\hline \multicolumn{4}{c}{$\chi^{2}=33,511 ; \mathrm{g}=1 ; \mathrm{p}=0,000$}
\end{tabular}

45 Naslov notografskega programa v odgovoru anketiranca ni bil naveden. 
Tabela 4: Vrste spletnih učilnic, ki so jih uporabljali učitelji pred epidemijo covid-19 in po njej

\begin{tabular}{l|r|r}
\cline { 2 - 3 } & \multicolumn{1}{r}{ f pred } & f po \\
\hline Spletna učilnica Arnes (sistem Moodle) & 6 & 13 \\
\hline Engrade & 1 & $/$ \\
\hline Edmodo & 1 & $/$ \\
\hline Google Classroom/Učilnica & 1 & 4 \\
\hline Easistent (Xooltime) & $/$ & 10 \\
\hline Microsoft Teams & $/$ & 4 \\
\hline
\end{tabular}

Pri vprašanju, ali učitelji uporabljajo spletno učilnico, so bile razlike med odgovori za uporabo pred epidemijo covid-19 in po njej statistično pomembne. Po razglašeni epidemiji je spletno učilnico uporabljala dobra polovica učiteljev $(54,9 \%)$, pred njo pa dobra desetina (12,2 \%). Pri odgovorih, katero spletno učilnico so uporabljali, vidimo večjo raznolikost uporabe po epidemiji. Če je bila pred epidemijo covid-19 med učitelji glasbe najbolj razširjena uporaba Arnesove spletne učilnice (sistem Moodle), so po njej začeli poleg te uporabljati tudi spletne učilnice v eAsistentu (Xooltime) in Googlu (Google Učilnica) ter sodelovalno okolje MS Teams.

RV 2: Ali so se pri učiteljih glasbene umetnosti pojavljale razlike pred epidemijo covid-19 in po njej glede uporabe drugih spletnih platform oz. aplikacij pri pouku glasbene umetnosti?

Tabela 5: Uporaba drugih spletnih platform oz. aplikacij pred epidemijo in po njej ter vrednost hi-kvadrat preizkusa

\begin{tabular}{l|l|r|r|r}
\cline { 3 - 5 } \multicolumn{2}{c}{} & $\boldsymbol{d a}$ & $\boldsymbol{n e}$ & skupaj \\
\hline \multirow{3}{*}{ pred } & $\mathrm{F}$ & 26 & 57 & 83 \\
\cline { 2 - 5 } & $\mathrm{f} \%$ & $31,3 \%$ & $68,7 \%$ & $100,0 \%$ \\
\hline \multirow{3}{*}{ po } & $\mathrm{F}$ & 46 & 37 & 83 \\
\cline { 2 - 5 } & $\mathrm{f} \%$ & $55,4 \%$ & $44,6 \%$ & $100,0 \%$ \\
\hline \multirow{2}{*}{ skupaj } & $\mathbf{F}$ & $\mathbf{7 2}$ & $\mathbf{9 4}$ & $\mathbf{1 6 6}$ \\
\cline { 2 - 5 } & $\mathbf{f} \%$ & $\mathbf{4 3 , 4} \%$ & $\mathbf{5 6 , 6} \%$ & $\mathbf{1 0 0 , 0} \%$ \\
\hline \multicolumn{4}{c}{$\chi^{2}=9,811 ; \mathrm{g}=1 ; \mathrm{p}=0,002$} \\
\cline { 2 - 5 }
\end{tabular}

Med uporabo spletnih platform oz. aplikacij pri pouku glasbene umetnosti se pred epidemijo covid-19 in po njej pojavljajo statistično pomembne razlike. Pred epidemijo je spletne platforme oz. aplikacije uporabljala slaba tretjina 
(31,3\%), po njej pa več kot polovica učiteljev (55,4\%). Pred epidemijo so največ uporabljali YouTube $(f=10)$, po njej pa Zoom $(f=15)$. Po epidemiji je YouTube uporabljalo 12 učiteljev, Googlove aplikacije (Site, Drive, Forms, Meet, prosojnice, Učilnica) je uporabljalo devet učiteljev. Pred epidemijo so po trije učitelji uporabljali Kahoot (enako tudi trije po epidemiji) in Zoom, po dva Padlet (po epidemiji štirje učitelji), Prezi in Skype (po štirje), po eden pa Audacity, Finale, Plickers, Mentimeter, Wooclap, Collage maker, Nearpod, Virtual piano, Garage band, Singing fingers, Tabla, Metronom in Db-meter. Po epidemiji covid-19 sta Mentimeter, Acapella, Chrome Music Lab in WeTransfer uporabljala po dva učitelja, po en učitelj pa Finale, Cisco Webex, Plickers, Wooclap, Prezi, Sibelius, Webinar, Quizzis in Music Maker. Ugotavljamo, da se je raznolikost uporabe spletnih platform oz. aplikacij po epidemiji covid-19 povečala, kar se zdi pomembno za nadaljnje poučevanje.

V nadaljevanju so nas zanimale izkušnje učiteljev s poučevanjem glasbene umetnosti na daljavo med epidemijo covid-19.

Tabela 6: Odgovori učiteljev o tem, ali so imeli v obdobju dela na daljavo med epidemijo covid-19 in po njej težave $\mathrm{z}$ uporabo IKT pri pouku glasbene umetnosti

\begin{tabular}{lr|r} 
& $\boldsymbol{f}$ & $\boldsymbol{f} \%$ \\
\hline ne & 32 & 39,0 \\
\hline $\mathrm{da}$ - imel/-a sem tehnične težave z uporabo IKT & 16 & 19,5 \\
\hline $\begin{array}{l}\text { da - imel/-a sem težave, kako uresničiti predvidene cilje, opredeljene } \\
\text { v učnem načrtu (izvajanje, poslušanje, ustvarjanje) }\end{array}$ & 23 & 28,0 \\
\hline da - imel/-a sem težave pri komunikaciji z učenci & 6 & 7,3 \\
\hline da - drugo & 5 & 6,1 \\
\hline skupaj & $\mathbf{8 2}$ & $\mathbf{1 0 0 , 0}$ \\
\hline
\end{tabular}

Iz tabele 6 je razvidno, da je imela več kot polovica učiteljev $(61,0 \%) \mathrm{v}$ obdobju epidemije covid-19 (med njo in po njej) težave z uporabo IKT pri pouku glasbene umetnosti na daljavo. Največ jih je imelo težave, kako uresničiti predvidene cilje, opredeljene $\mathrm{v}$ aktualnem učnem načrtu (28 \%), sledile so tehnične težave $\mathrm{z}$ uporabo IKT $(19,5 \%)$ in težave pri komunikaciji $\mathrm{z}$ učenci $(7,3 \%)$. Nekaj učiteljev je navedlo druge tovrstne težave $(6,1 \%)$, in sicer neodzivnost učencev, neznanje ali pomanjkljivo znanje na področju učinkovite rabe IKT (izpostavili so predvsem uporabo spletnih učilnic, programov, video- in avdioposnetkov). 
Tabela 7: Odgovori učiteljev o tem, ali so imeli učenci pri pouku glasbene umetnosti na daljavo težave pri uporabi IKT

\begin{tabular}{l|r|r}
\cline { 2 - 3 } \multicolumn{1}{c|}{} & $\boldsymbol{f}$ & $\boldsymbol{f} \%$ \\
\hline da & 28 & 33,7 \\
\hline ne & 55 & 66,3 \\
\hline skupaj & $\mathbf{8 3}$ & $\mathbf{1 0 0 , 0}$ \\
\hline
\end{tabular}

$\mathrm{Na}$ vprašanje, ali so imeli učenci pri pouku glasbene umetnosti na daljavo težave pri uporabi IKT, je tretjina učiteljev odgovorila pritrdilno, 66,3 \% pa jih navaja, da učenci težav niso imeli. Kot najpogostejše težave učencev so navedli probleme na področju računalniške strojne in programske opreme (slaba oziroma neustrezna oprema, težave pri uporabi računalnika oz. onemogočen dostop do računalnika, uporaba programov, aplikacij), tehnične težave (dostop do interneta - onemogočena ali slaba internetna povezava) in pomanjkanje znanja za uporabo IKT (uporaba elektronske pošte, e-učbenikov, spletnih učilnic, ustvarjanje ter pošiljanje video- in avdioposnetkov, ustvarjanje ter pošiljanje datotek). Kot je razvidno iz odgovorov, so učitelji težave reševali sproti in po korakih - pogosto so komunicirali z učenci in po potrebi tudi s starši prek telefona oz. elektronske pošte, priporočili so ogled videonavodil, ki so dostopna na YouTube, pošiljali pisna navodila, posamezne šole so celo nudile možnost pri izposoji računalnikov.

Učitelje glasbene umetnosti smo prav tako prosili, da ocenijo (od zelo slabo do zelo dobro) svoje znanje uporabe IKT pri pouku glasbene umetnosti pred epidemijo covid-19 in po njej.

RV 3: Ali so se pri učiteljih glasbene umetnosti pojavljale razlike pred epidemijo covid-19 in po njej glede ocene znanja uporabe IKT pri pouku glasbene umetnosti?

Tabela 8: Ocena znanja uporabe IKT pri pouku glasbene umetnosti pred epidemijo covid-19 in po njej ter vrednosti t-testa za parne primerjave

\begin{tabular}{l|r|r|r|r|r|r}
\cline { 2 - 5 } & $\boldsymbol{N}$ & $\boldsymbol{M}$ & St. Odklon & $\boldsymbol{t}$ & $\boldsymbol{g}$ & $\boldsymbol{P}$ \\
\hline pred & 81 & 3,40 & 1,008 & \multirow{2}{*}{$-3,162$} & 80 & 0,002 \\
\cline { 1 - 4 } med oz. po & 81 & 3,58 & 0,947 & & & \\
\hline
\end{tabular}

$\mathrm{N}=$ numerus; $\mathrm{M}$ = aritmetična sredina; St. odklon = standardni odklon; $\mathrm{t}=$ vrednost $\mathrm{t}$-testa za parno primerjavo; $\mathrm{g}=$ prostostne stopinje; $\mathrm{p}=$ stopnja tveganja.

Ugotavljamo, da so učitelji glasbene umetnosti svoje znanje uporabe IKT višje ocenili za obdobje po epidemiji covid-19 $(\mathrm{M}=3,58)$ kot pred covid-19 $(\mathrm{M}=3,40)$. Razlike so bile statistično pomembne. 
Tabela 9: Odgovori učiteljev na vprašanje, ali so se pred epidemijo covid-19 udeležili kakšnega izobraževanja iz varne in kritične uporabe IKT pri pouku

\begin{tabular}{l|r|r}
\cline { 2 - 3 } & $\boldsymbol{f}$ & $\boldsymbol{f} \%$ \\
\hline ne & 24 & 29,6 \\
\hline da & 57 & 70,4 \\
\hline izmepaj & $\mathbf{8 1}$ & $\mathbf{1 0 0 , 0}$ \\
\hline da - vsebine smo obravnavali v okviru študija & $f$ & $f \%$ \\
\hline $\begin{array}{l}\text { da - udeležil/-a sem se izobraževanja v okviru zaposlitve (stalno } \\
\text { strokovno izpopolnjevanje) }\end{array}$ & 7 & 12,3 \\
\hline da - izobraževanja sem se udeležil/-a v prostem času & 42 & 73,7 \\
\hline da - drugo & 3 & 5,2 \\
\hline skupaj & 5 & 8,8 \\
\hline
\end{tabular}

Rezultati kažejo, da se je kar 70,4 \% učiteljev pred epidemijo covid-19 udeležilo izobraževanja iz varne in kritične uporabe IKT pri pouku, izmed teh večina $(73,7 \%)$ v okviru stalnega strokovnega izpopolnjevanja v okviru zaposlitve, manj jih je vsebine obravnavalo v okviru študija ter se na to temo izobraževalo v prostem času. Med tistimi, ki so navedli drugo, je en učitelj odgovoril, da se je izobraževal v okviru študija, na njihovi šoli pa znanje redno dopolnjuje njihova računalničarka s tedenskimi izobraževanji uporabe IKT.

Tabela 10: Odgovori učiteljev na vprašanje, ali so imeli v obdobju med epidemijo covid-19 oz. po njej v okviru njihove ustanove organizirano kakšno usposabljanje iz varne in kritične uporabe IKT

\begin{tabular}{l|r|r}
\cline { 2 - 3 } & $f$ & $f \%$ \\
\hline da (navedite tematiko) & 44 & 54,3 \\
\hline ne & 37 & 45,7 \\
\hline skupaj & $\mathbf{8 1}$ & $\mathbf{1 0 0 , 0}$ \\
\hline
\end{tabular}

Nekaj več kot polovica učiteljev (54,3 \%) je na vprašanje, ali so imeli med epidemijo covid-19 in po njej v okviru svoje ustanove organizirano kakšno usposabljanje iz varne in kritične uporabe IKT, odgovorila pritrdilno, kar nekoliko preseneča, saj bi v danih razmerah pričakovali višji rezultat. Učitelji so se izobraževali na pričakovanih področjih učinkovite rabe IKT pri delu na daljavo - največ na področju spletne učilnice Arnes, eAsistent $(f=15)$ in sodelovalnega okolja MS Teams ( $f=12)$, nekaj manj o varni uporabi interneta $(f=8)$, nekaj pa tudi o Google Učilnica ter programih in aplikacijah Cisco Webex, Zoom idr. 
Tabela 11: Kako so učitelji pridobili/nadgradili znanje za izvajanje pouka na daljavo med epidemijo covid-19 oz. po njej

\begin{tabular}{lr|r}
\cline { 2 - 3 } & $f$ & $f \%$ \\
\hline $\begin{array}{l}\text { znanja nisem nadgradil/-a, ker sem že pred epidemijo covid-19 } \\
\text { uporabljal/-a IKT pri pouku na visoki ravni }\end{array}$ & 2 & 2,5 \\
\hline znanja nisem nadgradil/-a, ker se mi ni zdelo potrebno & 1 & 1,2 \\
\hline znanje sem nadgradil/-a z lastnim učenjem & 44 & 54,3 \\
\hline $\begin{array}{l}\text { znanje sem nadgradil/-a v okviru organiziranih izobraževanj in } \\
\text { usposabljanj }\end{array}$ & 28 & 34,6 \\
\hline drugo & 6 & 7,4 \\
\hline skupaj & $\mathbf{8 1}$ & $\mathbf{1 0 0 , 0}$ \\
\hline
\end{tabular}

Predvidevali smo, da učitelji znanja niso nadgrajevali le v okviru izobraževanj, organiziranih na ustanovah zaposlitve, saj jih je, kot je razvidno iz tabele 11 , več kot polovica $(54,3 \%)$ znanje nadgrajevala $z$ lastnim učenjem, dobra tretjina v okviru organiziranih izobraževanj in usposabljanj, trije pa znanja niso nadgrajevali. Tudi odgovori "pod drugo« nam dajo jasnejši vpogled v situacijo, v kateri so se znašli učitelji. Med drugim so omenjali »medsebojno pomoč kolegov« in povedali, da so "padli v covid, in to vsi nepripravljeni«, pomagali so si $\mathrm{z}$ »raznimi spletnimi tutoriali za nove aplikacije in njihove podrobnosti«, nenazadnje pa je bilo »veliko lastne angažiranosti, ker je bilo usposabljanj bistveno premalo za kompleksno uporabo pri delu.«

Tabela 12: Ali bi si učitelji glasbene umetnosti želeli več izobraževanj na področju varne in kritične uporabe IKT pri pouku glasbe

\begin{tabular}{l|r|r}
\cline { 2 - 3 } \multicolumn{1}{c|}{} & \multicolumn{1}{c|}{$\boldsymbol{f}$} & \multicolumn{1}{c}{$\boldsymbol{f} \%$} \\
\hline da (navedite tematiko) & 45 & 56,3 \\
\hline ne & 35 & 43,7 \\
\hline skupaj & $\mathbf{8 0}$ & $\mathbf{1 0 0 , 0}$ \\
\hline
\end{tabular}

Večina učiteljev (56,3 \%) je odgovorila, da bi si želela več izobraževanj na področju varne in kritične uporabe IKT pri pouku glasbene umetnosti. Kot najbolj želene tematike tovrstnih izobraževanj so poudarili: predstavitev najučinkovitejših programov in aplikacij, ki bi bili primerni za uporabo učencev (ustvarjanje, snemanje avdio- in videoposnetkov, notno opismenjevanje) $(\mathrm{f}=$ 17) ter učinkovito uporabo spletnih učilnic (višja raven) $(f=5)$ in sodelovalnega okolja MS Teams $(f=3)$. 
RV 4: Ali so se pri učiteljih glasbene umetnosti pojavljale razlike pred epidemijo covid-19 in po njej glede ocene stopnje digitalne pismenosti?

Tabela 13: Ocena (od zelo slabo do zelo dobro) stopnje digitalne pismenosti pred epidemijo covid-19 in po njej ter rezultati t-testa za parno primerjavo

\begin{tabular}{|c|c|c|c|c|c|c|}
\hline & $N$ & $M$ & St. odklon & $t$ & $g$ & $p$ \\
\hline pred & 81 & 3,43 & 1,012 & \multirow{2}{*}{$-4,642$} & \multirow{2}{*}{80} & \multirow{2}{*}{0,000} \\
\hline med oz. po & 81 & 3,67 & ,935 & & & \\
\hline
\end{tabular}

$\mathrm{N}$ = numerus, $\mathrm{M}=$ aritmetična sredina, St. odklon = standardni odklon, $\mathrm{t}=$ vrednost $\mathrm{t}$ testa za parno primerjavo, $\mathrm{g}$ = prostostne stopinje, $\mathrm{p}=$ stopnja tveganja.

Razlike ocene stopnje digitalne pismenosti učiteljev glasbene umetnosti pred epidemijo covid-19 in med njo oz. po njej so statistično pomembne, in sicer so učitelji ocenili, da je bila njihova digitalna pismenost višja po epidemiji $(\mathrm{M}=3,67)$ kakor pred njo $(\mathrm{M}=3,43)$.

V nadaljevanju smo učitelje $z$ dvema odprtima vprašanjema povprašali, kje vidijo prednosti oz. pomanjkljivosti/slabosti uporabe IKT pri pouku glasbene umetnosti. Pri prednostih uporabe IKT pri pouku glasbene umetnosti so poudarili predvsem: lažjo organizacijo (boljšo dostopnost in preglednost informacij) in izvajanje pouka, sodobnejši pristop, nazornejšo predstavitev ter posledično približanje vsebin učencem in zato zanimivejši pouk (izmenjava gradiv), boljše razumevanje glasbenih vsebin, boljšo komunikacijo in sodelovanje med učenci $\mathrm{z}$ uporabo spletnih učilnic, videokonferenčnega sistema Zoom, sodelovalnega okolja MS Teams, preprostejše ustvarjanje avdio- in videovsebin, povečano motivacijo in samostojnost učencev, preprostejši dostop do gradiv, bolj osredinjeno, po možnosti tudi večkratno poslušanje avdio- in videovsebin. Pri pomanjkljivostih oz. slabostih pa so učitelji navedli: odsotnost osebnega stika, prekomerno posvečanje časa tehnologiji, problematiko izpada internetne povezave in nedelovanja strojne in programske opreme ter nevarnost večinske uporabe IKT, ker se na ta račun zmanjša dejavnostno delo pri pouku glasbene

Tabela 14: Na katerem področju se učiteljem pri pouku glasbene umetnosti zdi najbolj smiselna uporaba IKT

\begin{tabular}{l|r|r}
\cline { 2 - 3 } & $f$ & $f \%$ \\
\hline izvajanje & 5 & 6,6 \\
\hline poslušanje & 61 & 80,3 \\
\hline ustvarjanje & 9 & 11,8 \\
\hline uporaba IKT se mi ne zdi smiselna pri pouku glasbe & 1 & 1,3 \\
\hline skupaj & $\mathbf{7 6}$ & $\mathbf{1 0 0 , 0}$ \\
\hline
\end{tabular}


umetnosti, kar je bistveno. Zadnje je zaokroženo izpostavil/-a tudi eden/ena izmed vprašanih: »Odzivnost na glasbo, izvajanje glasbe v živo oz. poslušanje se nikoli ne more primerjati niti $\mathrm{z}$ najboljšo tehnologijo. Glasba so vibracije, ki se te dotaknejo neposredno [...].«

Temeljna področja glasbenih dejavnosti so: izvajanje, poslušanje in ustvarjanje. Poudarjamo, da se področja med seboj prepletajo in da naj bi jih učitelji glasbene umetnosti redno vključevali v svoj pouk, tudi $\mathrm{z}$ inovativno uporabo IKT. Kot je razvidno iz tabele 14 , večina $(80,3 \%)$ anketiranih učiteljev meni, da je najbolj smiselna uporaba IKT na področju poslušanja, kar je tudi pričakovano. $11,8 \%$ se zdi najbolj smiselna uporaba na področju ustvarjanja, 6,6 \% pa na področju izvajanja. Uporaba IKT pri pouku glasbene umetnosti se ne zdi smiselna $1,3 \%$ učiteljem.

Tabela 15: Odgovori učiteljev o tem, v kolikšni meri bodo po svojem mnenju $\mathrm{v}$ prihodnje pri pouku glasbene umetnosti uporabljali IKT

\begin{tabular}{l|r|r}
\cline { 2 - 3 } & \multicolumn{1}{c|}{$\boldsymbol{f}$} & \multicolumn{1}{c}{$\boldsymbol{f} \%$} \\
\hline ne bom uporabljal/-a & 1 & 1,3 \\
\hline manj kot 50\% & 16 & 21,1 \\
\hline $50 \%-69 \%$ & 37 & 48,7 \\
\hline $70 \%-89 \%$ & 14 & 18,4 \\
\hline $90 \%$ ali več & 8 & 10,5 \\
\hline skupaj & $\mathbf{7 6}$ & $\mathbf{1 0 0 , 0}$ \\
\hline
\end{tabular}

Več kot tri četrtine $(77,6 \%)$ učiteljev meni, da bodo v prihodnje uporabljali IKT pri pouku glasbene umetnosti v $50 \%$ ali več, pred epidemijo covid-19 pa jih je v $50 \%$ ali več IKT uporabljalo $62,7 \%$. V prihodnje jih namerava največ uporabljati IKT med $50 \%$ in $69 \%$ (48,7\%).

\section{Zaključek}

Izbruh koronavirusne bolezni (covid-19) po svetu in pri nas ter posledična razglasitev epidemije sta pomembno vplivala tudi na spremembe na področju pouka glasbene umetnosti v osnovnošolskem izobraževanju. Učinkovita uporaba IKT je v 21. stoletju postala tako rekoč ena večjih zahtev sodobne družbe in dejansko edina možnost za nadaljevanje izobraževalnega procesa, ki je v navedenem obdobju potekal na daljavo. Posledično je bilo treba iskati nove možnosti preoblikovanja glasbenega pouka, kar je bil za učitelje in tudi za učence svojevrsten izziv.

Skoraj tretjina anketiranih učiteljev je pri pouku glasbene umetnosti uporabljala IKT v manj kot $50 \%, \mathrm{v} 90 \%$ in več ga je uporabljala skoraj petina (19,3\%), štirje pa ga niso uporabljali. Ugotavljamo, da je $43 \%$ učiteljev 
uporabljalo IKT kot didaktični pripomoček pri svojemu delu, za predvajanje videoposnetkov, četrtina jih je najpogosteje uporabljala IKT za predvajanje avdio posnetkov, slaba desetina $(8,9 \%)$ pa kot pripomoček za delo učencev.

Izpostavljamo, da je pred razglasitvijo epidemije spletno učilnico uporabljalo le 12,2 \% učiteljev glasbene umetnosti, po razglasitvi epidemije pa je delež narasel kar za 42,7 odstotne točke (na 54,9\%), kar je - glede na izvajanje pouka na daljavo - pričakovano. Pred epidemijo covid-19 je bila med učitelji glasbe najbolj razširjena uporaba Arnesove spletne učilnice (sistem Moodle), po covid-19 pa so začeli poleg te uporabljati tudi spletne učilnice v eAsistentu (Xooltime) in Googlu (Google Učilnica) ter sodelovalno okolje MS Teams.

Poudarjamo, da so po epidimiji covid-19 učitelji glasbene umetnosti za 24,1 odstotne točke več uporabljali druge spletne platforme oz. aplikacije, pomembno pa se je povečala tudi raznolikost. Če so pred epidemijo covid-19 pretežno uporabljali le YouTube, so po njej začeli uporabljati številne druge, npr. Zoom, Prezi, Skype, Googlove aplikacije (Site, Drive, Forms ...), Padlet, Plickers, Garage band, Singing fingers, Tabla, Metronom, Mentimeter, Acapella, Chrome Music Lab, kar je pravzaprav izjemnega pomena za oblikovanje nadaljnjega poučevanja $z$ inovativno uporabo IKT.

Izkušnje učiteljev s poučevanjem glasbene umetnosti na daljavo v času med epidemijo covid-19 in po njej kažejo, da je več kot polovica učiteljev (61,0 \%) imela težave $z$ uporabo IKT, in sicer največ na področju uresničevanja predvidenih ciljev, opredeljenih $\mathrm{v}$ aktualnem učnem načrtu (28 \%), manjši delež je imel tehnične težave z uporabo IKT $(19,5 \%)$ in težave pri komunikaciji z učenci $(7,3 \%)$. Nekaj učiteljev je navedlo druge težave $(6,1, \%)$, in sicer neodzivnost učencev, neznanje ali pomanjkljivo znanje na področju učinkovite rabe IKT (izpostavili so predvsem uporabo spletnih učilnic, programov, video- in avdioposnetkov). Ugotovili smo, da čeprav so se učitelji sami spoprijemali s težavami z uporabo IKT, težav pri učencih med izvajanjem pouka na daljavo pretežno $(66,3 \%)$ ni bilo opaziti. Pri učencih, ki so se soočali s težavami, so učitelji kot najpogostejše težave navedli probleme na področju računalniške strojne in programske opreme ter tehnične težave in pomanjkanje znanja za uporabo IKT. Učitelji so težave reševali sproti in postopno, po korakih skozi redno komunikacijo $\mathrm{z}$ učenci in po potrebi tudi s starši.

Ocena znanja uporabe IKT pri pouku glasbene umetnosti pred epidemijo covid-19 in po njej kaže, da so učitelji svoje znanje uporabe IKT višje ocenili za obdobje po epidemiji covid-19 $(\mathrm{M}=3,58)$ kot pred njo $(\mathrm{M}=3,40)$. Kar 70,4 $\%$ učiteljev se je pred epidemijo covid-19 udeležilo izobraževanja iz varne in kritične uporabe IKT pri pouku, izmed teh večina $(73,7 \%)$ v okviru stalnega strokovnega izpopolnjevanja v okviru zaposlitve, manj jih je vsebine obravnavalo $\mathrm{v}$ okviru študija ter se na to temo izobraževalo $\mathrm{v}$ prostem času.

$\mathrm{V}$ nasprotju z našim pričakovanjem je le nekaj več kot polovica učiteljev glasbene umetnosti $(54,3 \%)$ imela med epidemijo covid-19 in po njej 
organizirano usposabljanje iz varne in kritične uporabe IKT (pretežno na področju delovanja spletnih učilnic in sodelovalnih okolij) v okviru svoje ustanove, a se je njihova ocena znanja uporabe IKT kljub temu zvišala, verjetno tudi zato, ker se je dobra polovica učiteljev samoizobraževala na tem področju $(54,3 \%)$, dobra tretjina pa v okviru drugih organiziranih izobraževanj in usposabljanj. V prihodnje bi si jih več želelo več izobraževanj na področju višje ravni učinkovite uporabe spletnih in na področju sodelovalnega okolja MS Teams. Prav tako so izrazili željo po predstavitvi najučinkovitejših programov in aplikacij, ki bi bili primerni za uporabo učencev pri pouku glasbene umetnosti.

Raziskava ocene stopnje digitalne pismenosti učiteljev glasbene umetnosti kaže, da je njihova digitalna pismenost višja po epidemiji covid-19 $(\mathrm{M}=3,67)$ kot pred njo $(\mathrm{M}=3,43)$. Velika večina učiteljev glasbene umetnosti v osnovnošolskem izobraževanju vidi prednosti uporabe IKT pri pouku. Poudarili so lažjo organizacijo in izvajanje pouka, sodobnejši pristop, nazornejšo predstavitev ter posledično približanje vsebin učencem in zato zanimivejši pouk, boljše razumevanje glasbenih vsebin, boljšo komunikacijo ter sodelovanje med učenci z uporabo spletnih učilnic in sodelovalnih okolij, preprostejše ustvarjanje avdio- in videovsebin, povečano motivacijo pa tudi samostojnost učencev, preprostejši dostop do gradiv, bolj osredinjeno, po možnosti tudi večkratno poslušanje avdio- in videovsebin. Kot pomanjkljivosti oz. slabosti pa so navedli odsotnost osebnega stika, prekomerno posvečanje časa tehnologiji, problematiko izpada svetovnega spleta ter nedelovanja strojne in programske opreme ter nevarnost večinske uporabe IKT, ker se tako zmanjša dejavnostno delo pri pouku glasbene umetnosti, kar je bistveno. Kljub vsemu pa kar 80,3 \% učiteljev meni, da je vključevanje IKT najbolj smiselno na področju poslušanja, 11,8 \% se zdi najbolj smiselna uporaba na področju ustvarjanja, 6,6 \% pa na področju izvajanja. Izpostavljamo, da več kot tri četrtine $(77,6 \%)$ učiteljev meni, da bodo v prihodnje uporabljali IKT pri pouku glasbene umetnosti v $50 \%$ ali več, pred epidemijo covid-19 pa jih je v $50 \%$ ali več IKT uporabljalo $62,7 \%$. Odstotek učiteljev, ki nameravajo v prihodnje uporabljati IKT pri pouku glasbene umetnosti, se je torej povišal za skoraj 15 odstotnih točk.

Ustrezna digitalna pismenost učiteljev glasbene umetnosti $\mathrm{v}$ današnjem času vsekakor predstavlja svojevrstno obvezo, saj pomembno vpliva na kakovostno doseganje učnih ciljev, motivacijo in na učinkovitost $\mathrm{v}$ razredu in pri izvajanju pouka na daljavo, prav tako pa lahko učitelju v precejšnji meri celostno olajša delo. Treba pa je poudariti, da morajo v ospredju kakovostnega in sodobnega glasbenega pouka vedno ostati na učenca usmerjene dejavnosti - izvajanje, poslušanje in ustvarjanje -, učinkovita in ustvarjalna raba IKT pa mora biti v prihodnosti primerno umeščena $\mathrm{v}$ glasbeni pouk oz. mora ostati podpora poučevanju in ne prevladujoča aktivnost. 


\section{Bibliografija}

Breznik, Inge. Smernice za uporabo IKT pri predmetu glasbena umetnost v osnovni šoli in glasba v gimnaziji. Ljubljana: Zavod Republike Slovenije za šolstvo, 2016. Dostop 20. marec 2020. https://www.zrss.si/digitalnaknjiznica/smernice-ikt-gum/files/assets/basic-html/ index.html\#1.

Carretero, Stephanie, RiinaVuorikari in Yves Punie. DigComp 2.1: The Digital Competence Framework for Citizens with eight proficiency levels and examples of use. JointResearch Centre, European Commission, 2017. Dostop 25. februar 2020. https://publications. jrc.ec.europa.eu/repository/bitstream/JRC106281/web-digcomp2.1pdf_(online).pdf.

Carretero, Stephanie, RiinaVuorikari in Yves Punie. DigComp 2.1: Okvir digitalnih kompetenc za državljane; Osem ravni doseganja kompetenc in primeri rabe. Prevod. Ljubljana: Zavod RS za šolstvo, 2017.

Debevc, Matjaž, Jernej Weiss, Andrej Šorgo in Ines Kožuh. »Solfeggio Learning and the Influence of a Mobile Application Based on Visual, Auditory and Tactile Modalities.« British Journal of Educational Technology 51, št. 1 (2020): 177-193. Dostop 4. december 2020. https://doi.org/10.1111/bjet.12792.

"Digitalna kompetenca - vitalna veščina 21. stoletja za učitelje in učence." School Education Gateway - Evropska spletna platforma za šolsko izobraževanje. Dostop 13. januar 2020. https://www.schooleducationgateway.eu/s1/pub/resources/tutorials/digital-competence-the-vital-.htm.

"Digitalna pismenost. « Portal Osnowne spretnosti in veščine. Dostop 11. marec 2020. https:// www.portalosv.si/digitalna-pismenost/.

IBM Corp. Released 2013. IBM SPSS Statistics for Windows, Version 22.0. Armonk, NY: IBM Corp.

Javrh, Petra. »Digitalna pismenost nasproti digitalni kompetenci.« European Commission, EPALE - ePlatforma za izobraževanje odraslih v Evropi. Dostop 11. marec 2020. https://epale.ec.europa.eu/sl/blog/digitalna-pismenost-nasproti-digitalni-kompetenci.

Kampylis, Panagiotis, Yves Punie in Jim Devine. Promoting Effective Digital-Age LearningA European Framework for Digitally-Competent Educational Organisations. JointResearch Centre, European Commission, 2015. Dostop 5. marec 2020. https://publications.jrc. ec.europa.eu/repository/bitstream/JRC98209/jrc98209_r_digcomporg_final.pdf.

Lango, Jožko. »Poučevanje glasbene vzgoje $\mathrm{z}$ uporabo informacijsko-komunikacijske tehnologije. « Doktorska disertacija, Univerza v Ljubljani, 2011.

McClelland, David Clarence. »Testing for Competence Rather Than for 'Intelligence'.» American Psychologist 28, št. 1 (1973): 1-14. Dostop 27. februar 2020. https://www. therapiebreve.be/documents/mcclelland-1973.pdf.

Odlok o preklicu epidemije nalezljive bolezni SARS-CoV-2 (covid-19), 14. maj 2020. Uradni list $R S$, št. 68/2020. Dostop 27. oktober 2020. https://www.uradni-list.si/ glasilo-uradni-list-rs/vsebina/2020-01-1030/.

Odredba o prepovedi zbiranja ljudi $\mathrm{v}$ zavodih s področja vzgoje in izobraževanja ter univerzah in samostojnih visokošolskih zavodih, 12. marec 2020. Uradni list $R S$, št. 19/20, 22/20 in 25/20. Dostop 27. oktober 2020. http://www.pisrs.si/Pis.web/ pregledPredpisa?id=ODRE2547\#.

Odredba o razglasitvi epidemije nalezljive bolezni SARS-CoV-2 (covid-19) na območju Republike Slovenije, 12. marec 2020. Uradni list RS, št. 19/2020. Dostop 27. oktober 2020. https://www.uradni-list.si/glasilo-uradni-list-rs/vsebina/2020-01-0532.

Redecker, Christine. European Framework for the Digital Competence of Educators: DigCompEdu. JointResearch Centre, European Commission, 2017. Dostop 25. februar 2020. 
https://ec.europa.eu/jrc/en/publication/eur-scientific-and-technical-research-reports/ european-framework-digital-competence-educators-digcompedu.

Redecker, Christine. Evropski okvir digitalnib kompetenc izobraževalcev: DigCompEdu. Ljubljana: Zavod RS za šolstvo, 2017. Dostop 25. februar 2020. https://www.zrss.si/ digitalnaknjiznica/DigCopEdu/2/.

Roblyer, Margaret D. Integrating Educational Technology into Teaching. New Yersey: Pearson/ Merrill Prentice Hall, 2006.

Rotar Pance, Branka, in Tina Bohak Adam. »Vključevanje informacijsko-komunikacijske tehnologije v didaktično usposabljanje bodočih učiteljev glasbe." V Inovativna didaktična uporaba informacijsko komunikacijske tehnologije $v$ študijskem procesu, uredila Jože Rugelj in Vesna Ferk Savec, 263-279. Ljubljana: Univerza v Ljubljani, 2019. Dostop 14. februar 2020. https://repozitorij.uni-lj.si/IzpisGradiva.php?id=111359.

Šimunovič, Natalija. »Poučevanje inštrumenta v času epidemije covid-19.« Glasbenopedagoški zbornik Akademije za glasbo v Ljubljani 16, št. 32 (2020): 11-38.

»The European Digital Strategy.« European Commission: Strategy, Shaping Europe’s digital future. Dostop 11. marec 2020. https://ec.europa.eu/digital-single-market/en/content/ european-digital-strategy.

„UNICEF and Microsoft launch global learning platform to help address covid-19 education crisis.«Unicef. Dostop 27. oktober 2020. https://www.unicef.org/press-releases/ unicef-and-microsoft-launch-global-learning-platform-help-address-covid-19-education.

Urbančič, Matej, Marko Radovan, Mateja Bevčič, Sara Drožđek, Sanja Jedrinović, Anja Luštek, Jože Rugelj, Jurij Selan in Branka Rotar - Pance. Strokovne podlage za didaktično uporabo IKT v izobraževalnem procesu za področje umetnosti. Dostop 17. januar 2020. http://ikt-projekti.uni-lj.si/porocila/strokovne\%20podlage\%20umetnost.pdf.

Vuorikari, Riina. »Razvoj digitalnih kompetenc: naloga državljana 21. stoletja.«School Education Gateway - Evropska spletna platforma za šolsko izobraževanje. Dostop 13. januar 2020. https://www.schooleducationgateway.eu/s1/pub/viewpoints/experts/riina_vuorikari_-_becoming_dig.htm.

Webster, Peter Richard. »Computer-Based Techology and Music Teaching and Learning: 2000-2005."V International Handbook of Research in Arts Education, uredila Liora Bressler, 1311-1330. Vol. 16. Dordrecht: Springer, 2007.

Wechtersbach, Rado. »Digitalna kompetenca in njeno izgrajevanje." Organizacija (Kranj) 42, št. 1 (2009): A1-A5.

Wechtersbach, Rado. »Digitalna kompetenca in njeno izgrajevanje.« Zgodovina v šoli 20, št. 3/4 (2011): 2-9. 


\section{SUMMARY}

\section{Distance Teaching of Music in Primary School Education during the Pandemic COVID-19}

The outbreak of coronavirus disease (COVID-19) worldwide and in our country and the consequent declaration of an epidemic also significantly impacted primary schools' music education changes. In the $21^{\text {st }}$ century, the effective use of information and communications technology (ICT) has become the only option for continuing the educational process, which took place at the distance learning. As a result, it was necessary to look for new possibilities for transforming music lessons, which was a unique challenge for both teachers and students.

Before the epidemic's declaration, almost a third of the surveyed teachers used ICT, less than $50 \%$ in music lessons, mostly for playing videos, and only $12.2 \%$ of music teachers used the online classroom. After the epidemic declaration, the share increased by as much as 42.7 percentage points (to $54.9 \%$ ), which is a distance expected, and also other online platforms and applications were used by 24.1 percentage points more. The diversity of use has also increased significantly, which is extremely important for further teaching through ICT's innovative use.

Teachers' experience with distance teaching of music between and after COVID-19 shows that more than half of teachers $(61.0 \%)$ had problems using ICT, mostly in achieving the goals set out in the current curriculum (28\%). Although teachers themselves faced ICT problems, students' issues during distance learning were mostly not observed.

Just over half of the music teachers (54.3\%) had organized training in the safe and critical use of ICT during and after COVID-19 within their institutions, which is entirely contrary to our expectations. However, their assessment of ICT skills has nevertheless increased, probably because more than half of teachers had self-educated in this field.

A survey of the assessment of music teachers' digital literacy rate shows that their digital literacy is higher after COVID-19 $(\mathrm{M}=3.67)$ than before COVID-19 $(\mathrm{M}=3.43)$. The vast majority of music teachers in primary education see the benefits of using ICT in the classroom.

They pointed out more effortless organization and implementation of lessons, clearer presentations, more exciting classes, better communication and cooperation between students, and increased motivation and independence. As shortcomings or weaknesses include the lack of personal contact, excessive time spent on technology, the Internet connection failure, the loss of hardware and software, and the danger of majority use of ICT, as this reduces activity in music lessons, which is essential. It seems important to point out that the percentage of teachers who intend to use ICT in music lessons in the future has increased by almost 15 percentage points.

Appropriate digital literacy of music teachers today is undoubtedly a kind of commitment. It significantly affects the quality of learning goals, motivation, and efficiency, both in the classroom and in the implementation of distance learning, and can substantially facilitate the teacher's work. However, it should be pointed out that in the forefront of quality and modern music lessons must always remain student-centered activities - performance, listening and creating, practical and creative use of ICT in the future must be appropriately placed in music lessons or support for teaching must remain and not a principal activity. 


\section{O AVTORICAH}

TINABOHAKADAM (Tina.BohakAdam@ag.uni-lj.si) je docentka na oddelku za glasbeno pedagogiko Akademije za glasbo Univerze v Ljubljani. Raziskovalno se ukvarja z zgodovino operne in koncertne poustvarjalnosti ter $\mathrm{z}$ uvajanjem IKT tehnologije v pedagoške študijske programe. Je avtorica znanstvenih in strokovnih člankov ter monografij Julij Betetto (18851963) - nestor opernih in koncertnih pevcev (2015) in Hočem postati pevka - portret koncertne perke, altistke Marije Bitenc Samec (2018).

MIRA METLJAK (mira.metljak@pef.uni-lj.si) je asistentka za področje pedagoške metodologije in statistike na Pedagoški fakulteti Univerze v Ljubljani. Poleg tega sodeluje pri različnih slovenskih (trenutno npr. Inovativno učenje in poučevanje v visokem šolstvu - INOVUP) in mednarodnih projektih (trenutno npr. Erasmus+ Integrity).

\section{ABOUT THE AUTHORS}

TINA BOHAK ADAM (Tina.BohakAdam@ag.uni-1j.si) is an Assistant Professor in the Department of Music Education at the University of Ljubljana, Academy of Music. In her research, she focuses on the history of opera and concert performance and the introduction of ICT to education-related academic programs. She is the author of scientific and technical articles and monographs Julij Betetto (1885-1963) - nestor opernih in koncertnih pevcev (Julij Betetto (1885-1963) - Nestor of Opera and Concert Singers) (2015) and Hočem postati pevka portret koncertne pevke, altistke Marije Bitenc Samec (I Want to Become a Singer - a Portrait of Concert Singer, Alto Marija Bitenc Samec) (2018).

MIRA METLJAK (mira.metljak@pef.uni-lj.si) is an Assistant Professor in education methodology and statistics at the Faculty of Education University of Ljubljana. She also collaborates at different Slovene (at the moment, e.g., Innovative learning and teaching in higher education -INOVUP) and international (at the moment, e.g., Erasmus+ Integrity) projects. 